\title{
Propofol inhibits hepatocellular carcinoma growth and invasion through the HMGA2-mediated Wnt/ $\beta$-catenin pathway
}

\author{
WEI OU* ${ }^{*}$ JIE LV* ${ }^{*}$ XIAOHUA ZOU, YIN YAO, JINLI WU, JIAN YANG, ZHUMEI WANG and YAN MA \\ Department of Anesthesiology, The Affiliated Hospital of Guizhou Medical University, Guizhou, Guiyang 550001, P.R. China
}

Received December 14, 2015; Accepted December 23, 2016

DOI: $10.3892 /$ etm.2017.4253

\begin{abstract}
Propofol is a commonly used intravenous anesthetic in tumor surgery. Recently, studies have confirmed that propofol has an antitumor effect on hepatocellular carcinoma (HCC); however, the molecular mechanism underlying this effect has not been elucidated until now. The present study aimed to investigate the mechanism of propofol on HepG2 cell proliferation, apoptosis and invasion, focusing on High Mobility Group AT-Hook 2 (HMGA2)-mediated Wnt/ $\beta$-catenin pathway. The HepG2 cells were treated with various concentrations of propofol for $24 \mathrm{~h}$, the relative protein levels of HMGA2, Wnt3a, $\beta$-catenin, Snail Family Zinc Finger 1 and c-myc were determined by western blot analysis. HMGA2-pcDNA3.1 plasmid was transfected into the HepG2 cells to overexpress HMGA2. Cell proliferation, apoptosis and invasion were examined by MTT assays, flow cytometry and Transwell-matrigel invasion assays, respectively. The results showed that propofol suppressed HMGA2 expression and $\mathrm{Wnt} / \beta$-catenin signaling in a dose-dependent manner. Propofol was able to inhibit cell proliferation and invasion, and induce cell apoptosis of HepG2 cells; however, these effects were attenuated by HMGA2 overexpression. The suppressed $\mathrm{Wnt} / \beta$-catenin signaling in HepG2 cells by treatment with propofol was also reversed by HMGA2 overexpression. In conclusion, this study provided a novel mechanism underlying the anti-tumor function of propofol on HCC. To the best of our knowledge, the present study is the first to demonstrate that propofol could downregulate the expression of HMGA2, which inhibited the Wnt/ $\beta$-catenin pathway, thus leading to the inhibition of cell proliferation and invasion, as well as the apoptosis of HepG2 cells.
\end{abstract}

Correspondence to: Dr Wei Ou, Department of Anesthesiology, The Affiliated Hospital of Guizhou Medical University, 4 Beijing Road, Guizhou, Guiyang 550001, P.R. China

E-mail: ou_wei7766@163.com

"Contributed equally

Key words: propofol, High Mobility Group AT-Hook 2, $\mathrm{Wnt} / \beta$-catenin, hepatocellular carcinoma

\section{Introduction}

Hepatocellular carcinoma (HCC) is the third most frequent cause of tumor-related deaths in China $(1,2)$. Due to the high metastatic potential of HCC $(3,4)$, progression is found in approximately $70 \%$ of patients within one year of diagnosis (5), and it is difficult to treat patients with advanced HCC (6,7). It is therefore necessary to contrive novel anticancer reagents to prevent the invasiveness of HCC.

Propofol is one of the most extensively used intravenous anesthetic agents. Previous studies have confirmed that propofol also has an antitumor effect (8-12). Clinically relevant concentrations of propofol have the ability to inhibit cell proliferation, motility and invasion, and induce apoptosis of many cancer cells, such as HeLa, HT1080, HOS and RPMI-7951 (9). Zhang et al investigated the effect of propofol on liver cancer and found that propofol can effectively inhibit the proliferation and invasiveness of HCC cells, and induce apoptosis, in vitro $(13,14)$. In addition, Zhang et al demonstrated that propofol can inhibit tumor growth in tumor-bearing mice by activation of macrophages, thus exerting a therapeutic effect on HCC in vivo (15). However, the molecular mechanisms underlying the antitumor function of propofol on $\mathrm{HCC}$ has not been elucidated until now.

High Mobility Group AT-Hook 2 (HMGA2) is a member of the high mobility group family. It is essential for tumor progression and metastasis in vitro and in vivo (16). The role of HMGA2 in normal and HCC cell growth is well established (17,18). HMGA2 was reported to serve important functions in epithelial-mesenchymal transition (EMT) occurring in HCC, contributing to tumor growth and invasion (18). Recently, it has been suggested that HMGA2 acts as a transcriptional organizer of key signaling molecules $(19,20)$. Zha et al reported that the Wnt/ $\beta$-catenin pathway could be activated by HMGA2 (21).

To the best of our knowledge, the present study is the first to investigate whether propofol affects cell proliferation, apoptosis and invasion of HCC cells through the HMGA2 mediated Wnt $/ \beta$-catenin pathway, which may elucidate novel mechanisms underlying the antitumor function of propofol on HCC.

\section{Materials and methods}

Cell culture and drug treatment. The HepG2 cells (American Type Culture Collection, Manassas, VA, USA) were cultured 
in Dulbecco's modified Eagle's medium (HyClone; GE Healthcare, Logan, UT, USA) supplemented with $10 \%$ fetal bovine serum (FBS; HyClone), and maintained at $37^{\circ} \mathrm{C}$ in a humidified atmosphere with $5 \% \mathrm{CO}_{2}$. Following the use of miRanda prediction software (accessible: http://www .microrna.org/microrna/home.do), it was indicated that propofol may influence HMGA2 expression. Propofol was obtained from Corden Pharma S.p.A. (Latina, Italy), and diluted to concentrations of 5,10 and $20 \mu \mathrm{g} / \mathrm{ml}$ to treat the HepG2 cells for $24 \mathrm{~h}$.

Cell transfection. Cell transfection of pcDNA3.1 and HMGA2-pcDNA3.1 plasmid was performed using Lipofectamine ${ }^{\circledR} 2000$ (Invitrogen; Thermo Fisher Scientific, Inc., Carlsbad, CA, USA), according to the manufacturer's instructions. A negative control group were treated with Lipofectamine ${ }^{\circledR} 2000$ diluted in Opti-MEM ${ }^{\mathrm{TM}} \mathrm{I}$ (Gibco; Thermo Fisher Scientific, Inc.) only. Briefly, $5 \mu 1$ Lipofectamine ${ }^{\circledR} 2000$ and $100 \mathrm{ng}$ HMGA2-pcDNA3.1 plasmid were diluted in $250 \mu \mathrm{l}$ Opti-MEM ${ }^{\mathrm{TM}}$ I, respectively. After incubation at room temperature for $5 \mathrm{~min}$, the two solutions were mixed and incubated for $20 \mathrm{~min}$. Subsequently, the lipid-DNA complexes were added to the cell plates. After incubation at $37^{\circ} \mathrm{C}$ for $6 \mathrm{~h}$, the culture medium was replaced with fresh medium. Cells only treated with Lipofectamine ${ }^{\circledR} 2000$ were used as transfection control. After $48 \mathrm{~h}$, the transfection efficiency was assessed under the fluorescence microscope (N-STORM; Nikon Corporation, Tokyo, Japan). The cells were harvested for analysis when the transfection efficiency was $>80 \%$.

Western blot analysis. The HepG2 cells were harvested and lysed in RIPA Lysis Buffer (Sangon Biotech, Shanghai, China). The protein concentration was determined using a BCA Protein Assay kit (Sangon Biotech). A total of $20 \mu \mathrm{g}$ protein was loaded and separated by $10 \%$ SDS-polyacrylamide gel. The proteins were then transferred onto PVDF membranes (Merck Millipore, Billerica, MA, USA). After blocking in 3\% bovine serum albumin (Amresco, Inc., Solon, OH, USA) at $37^{\circ} \mathrm{C}$ overnight, the membranes were incubated with the primary antibodies at $37^{\circ} \mathrm{C}$ for $1 \mathrm{~h}$. The primary antibodies were as follows: Rabbit polyclonal to HMGA2 (ab52039; 1:800; Abcam, Cambridge, MA, USA), mouse monoclonal to Wnt3a (sc-136163; 1:400; Santa Cruz Biotechnology, Inc., Dallas, TX, USA), rabbit polyclonal to $\beta$-catenin (sc-7199; 1:400; Santa Cruz Biotechnology, Inc.), mouse monoclonal to Snail Family Zinc Finger 1 (Snail1) (\#3895; 1:500; Cell Signaling Technology, Inc., Beverly, MA, USA), rabbit polyclonal to c-myc (ab52039; 1:800; Abcam) and rabbit polyclonal to $\beta$-actin (\#40552; 1:1,000; Signalway Antibody Inc., College Park, MD, USA). The $\beta$-actin antibody was used as the internal control. After washing with Tris-buffered saline with Tween (Sangon Biotech) three times, the membranes were incubated with the secondary antibodies [goat anti-mouse IgG HRP conjugated antibody (\#L3032-2; 1:2,000; Signalway Antibody, Inc.), goat anti-rabbit IgG HRP conjugated antibody (ab6721; 1:5,000; Abcam)] at $37^{\circ} \mathrm{C}$ for $1 \mathrm{~h}$. The blots were detected using an ECL western blotting kit (Pierce Protein Biology; Thermo Fisher Scientific, Inc., Rockford, IL, USA) and analyzed using Image-Pro Plus version 6.0 software (Media Cybernetics, Inc., Rockville, MD, USA).
Cell proliferation assay. To determine cell proliferation, the 3-(4,5-dimethylthiazole-2-yl)-2,5-biphenyl tetrazolium bromide (MTT) assay was performed. The HepG2 cells were suspended into a density of $2 \times 10^{4}$ cells $/ \mathrm{ml}$, and $100 \mu \mathrm{l}$ cell suspension was added into each well of the 96-well plates. After incubation at $37^{\circ} \mathrm{C}$ for $0,24,48,72$ and $96 \mathrm{~h}$, $10 \mu \mathrm{l}$ MTT solution [5 $\mathrm{mg} / \mathrm{ml}$ in phosphate-buffered saline (PBS); Sigma-Aldrich; Merck KGaA, Darmstadt, Germany] was added into each well and incubated for $4 \mathrm{~h}$. The reaction product, formazan crystals, was dissolved by the addition of dimethyl sulfoxide. The absorbance at $570 \mathrm{~nm}$ was measured using a microplate reader (BioTek Instruments, Inc., Winooski, VT, USA).

Flow cytometry (FCM). Cell apoptosis rate was determined using an Annexin V-FITC/Propidium Iodide Apoptosis Detection kit (Kaiji Biological Inc., Nanjing, China) according to the manufacturer's instructions. Briefly, $5 \times 10^{5}$ cells were harvested and washed with PBS. Binding Buffer was added to resuspend the cells, and then the cells were stained with Annexin V and propidium iodide for $15 \mathrm{~min}$. Cell apoptosis was analyzed using FCM (Beckman Counter, Inc., Miami, FL, USA).

Cell invasion assay. Matrigel matrix (BD Biosciences, Franklin Lakes, NJ, USA) was added to the Transwell inserts (Corning, New York, NY, USA) at a final concentration of $200 \mu \mathrm{g} / \mathrm{ml}$ and allowed to polymerize at $37^{\circ} \mathrm{C}$ for $1 \mathrm{~h}$. The HepG2 cells were suspended in serum-free medium into a density of $5 \times 10^{4}$ cells $/ \mathrm{ml}$, and added to the upper chambers. The cell medium containing 10\% FBS was added to the lower chambers. The cell plates were then incubated at $37^{\circ} \mathrm{C}$ in a humidified atmosphere with $5 \% \mathrm{CO}_{2}$ overnight. After that, the non-invaded cells were removed by a cotton swab, and the invaded cells in the lower surface of the membrane were fixed with ethanol and stained with hematoxylin for $15 \mathrm{~min}$. The stained cells were counted under a microscope (Nikon Corporation).

Statistical analysis. All the data were analyzed using SPSS 19.0 statistical software (IBM SPSS, Armonk, NY, USA) and were presented as the mean \pm standard deviation. Statistical differences between the two groups were analyzed with the Student's t-test. $\mathrm{P}<0.05$ was considered to indicate a statistically significant difference.

\section{Results}

Effect of propofol on the expression of HMGA2. The effect of propofol on HMGA2 protein expression in HepG2 cells was examined by western blot analysis. The HepG2 cells were treated with 5,10 and $20 \mu \mathrm{g} / \mathrm{ml}$ propofol for $24 \mathrm{~h}$, and the relative protein level of HMGA2 was then examined. As shown in Fig. 1, HMGA2 expression was significantly inhibited by propofol in a dose-dependent manner. Propofol showed the maximum inhibitory effect on HMGA2 expression at the concentration of $20 \mu \mathrm{g} / \mathrm{ml}(\mathrm{P}<0.01)$.

Effect of propofol on the activation of Wnt/ $\beta$-catenin signaling. To investigate the effect of propofol on Wnt/ $\beta$-catenin signaling 

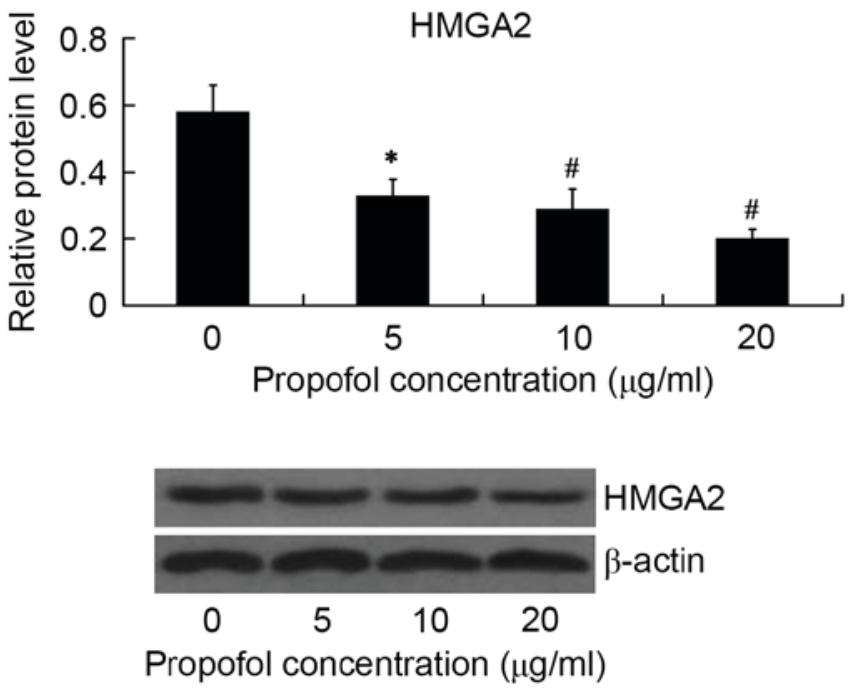

Figure 1. Expression of HMGA2 protein in HepG2 cells following treatment with propofol. ${ }^{*} \mathrm{P}<0.05$ and ${ }^{\#} \mathrm{P}<0.01$ vs. $0 \mu \mathrm{g} / \mathrm{ml}$. HMGA2, High Mobility Group AT-Hook 2.

activation, the relative protein levels of Wnt3a, $\beta$-catenin, Snaill and c-myc were examined in HepG2 cells following treatment with various concentrations of propofol for $24 \mathrm{~h}$. We found that the $\mathrm{Wnt} / \beta$-catenin signaling was significantly inhibited by propofol treatment at concentrations between 5 and $20 \mu \mathrm{g} / \mathrm{ml}$, as evidenced by decreased expression of Wnt3a, $\beta$-catenin, Snaill and c-myc in the propofol treatment groups compared with the $\beta$-actin control group. The lowest expression values were observed at propofol concentrations of $20 \mu \mathrm{g} / \mathrm{ml}(\mathrm{P}<0.01$; Fig. 2$)$ thus, cells were treated with $20 \mu \mathrm{g} / \mathrm{ml}$ propofol in all subsequent experiments.

Role of HMGA2 in mediating the effect of propofol on cell proliferation. HMGA2-pcDNA3.1 plasmid was transfected into HepG2 cells to overexpress HMGA2, and then the cells were treated with $20 \mu \mathrm{g} / \mathrm{ml}$ propofol for $24 \mathrm{~h}$. As expected, propofol inhibited HMGA2 expression; however, the relative protein level of HMGA2 was significantly increased in the propofol + HMGA2 group compared with the propofol group ( $\mathrm{P}<0.01$; Fig. 3).

Subsequently, we investigated whether HMGA2 mediates the effect of propofol on cell proliferation. Cells were transfected with HMGA2-pcDNA3.1 plasmid and treated with $20 \mu \mathrm{g} / \mathrm{ml}$ propofol for 24, 48, 72 and $96 \mathrm{~h}$, then an MTT assay was performed. As shown in Fig. 4, cell proliferation was significantly inhibited by propofol compared to the control group $(\mathrm{P}<0.05)$. Furthermore, it was found that HMGA2 overexpression reversed the inhibitory effect of propofol, as cell proliferation significantly increased compared to the propofol group $(\mathrm{P}<0.05$ and $\mathrm{P}<0.01)$.

Role of HMGA2 in mediating the effect of propofol on cell apoptosis. Next, we investigated whether HMGA2 mediates the effect of propofol on cell apoptosis by FCM analysis. The results revealed that compared with the cell apoptosis rate in the control group $(6.2 \pm 1.0 \%)$, treatment of $20 \mu \mathrm{g} / \mathrm{ml}$ propofol for $24 \mathrm{~h}$ significantly increased cell apoptosis rate to $8.8 \pm 1.2 \%(\mathrm{P}<0.05)$. However, the cell apoptosis rate was
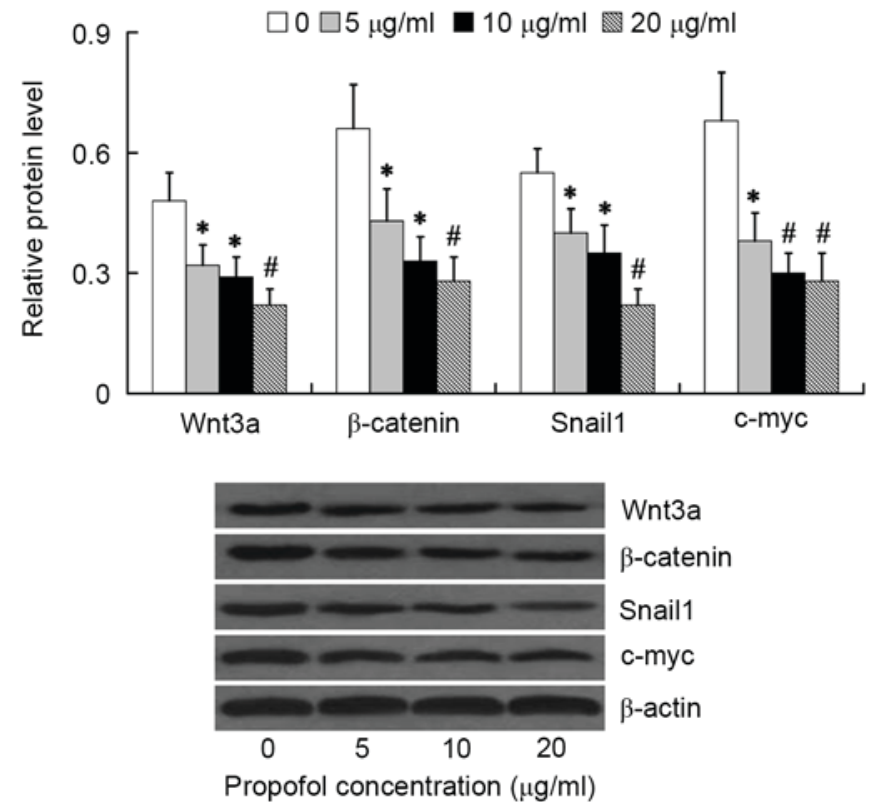

Figure 2. Expression of Wnt3a, $\beta$-catenin, Snaill and $c$-myc proteins in HepG2 cells following treatment with propofol. ${ }^{*} \mathrm{P}<0.05$ and ${ }^{\#} \mathrm{P}<0.01$ vs. $0 \mu \mathrm{g} / \mathrm{ml}$. Snaill, Snail Family Zinc Finger 1 .
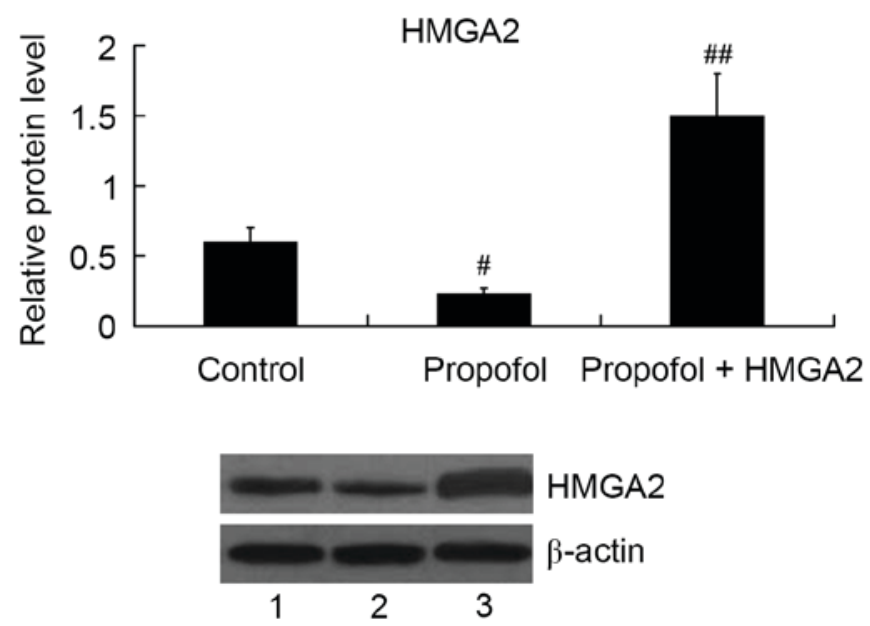

Figure 3. Expression of HMGA2 protein in HepG2 cells following treatment with propofol and transfection of HMGA2-pcDNA3.1 plasmid. Lane 1, control; lane 2, propofol; lane 3, propofol + HMGA2. ${ }^{\#} \mathrm{P}<0.01$ vs. control; ${ }^{\#} \mathrm{P}<0.01$ vs. propofol. HMGA2, High Mobility Group AT-Hook 2.

significantly decreased to $5.5 \pm 1.0 \%$ by transfection with the HMGA2-pcDNA3.1 plasmid ( $\mathrm{P}<0.05$; Fig. 5).

Role of HMGA2 in mediating the effect of propofol on cell invasion. To determine the role of HMGA2 in mediating the effect of propofol on cell invasion, a Transwell-matrigel cell invasion assay was performed. The results showed that compared with the control group, the number of invaded cells was significantly decreased in the propofol group $(\mathrm{P}<0.05)$; however, the inhibitory effect of propofol on cell invasion was reversed by transfection of the HMGA2-pcDNA3.1 plasmid ( $\mathrm{P}<0.01$; Fig. 6).

Role of HMGA2 in mediating the effect of propofol on Wnt/ $\beta$-catenin signaling activation. To investigate whether 


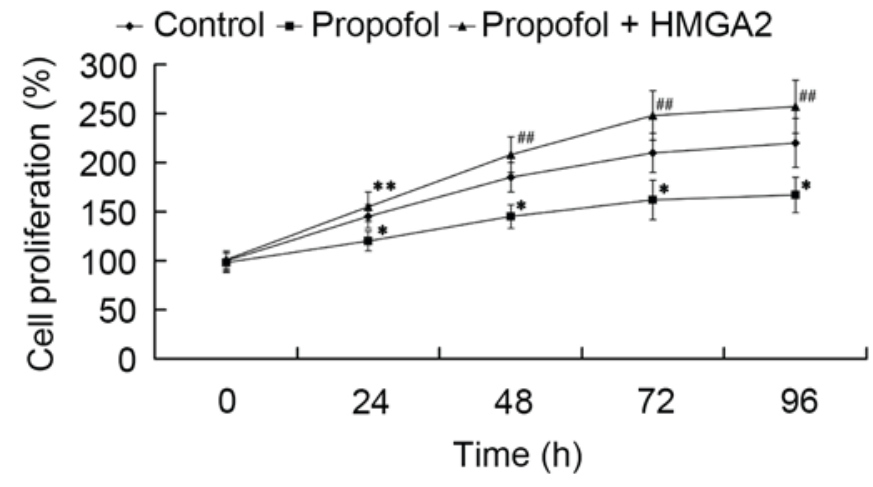

Figure 4. Role of HMGA2 in mediating the effect of propofol on cell proliferation. ${ }^{*} \mathrm{P}<0.05$ vs. control; ${ }^{* *} \mathrm{P}<0.05$ and ${ }^{\# \#} \mathrm{P}<0.01$ vs. propofol. HMGA2, High Mobility Group AT-Hook 2.

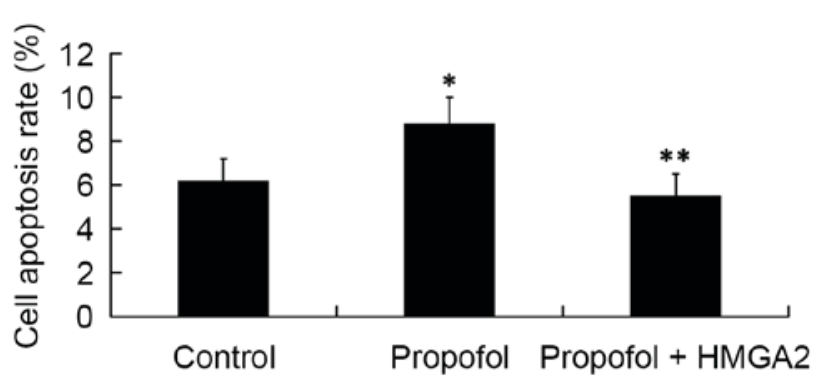

Figure 5. Role of HMGA2 in mediating the effect of propofol on cell apoptosis. ${ }^{*} \mathrm{P}<0.05$ vs. control; ${ }^{* *} \mathrm{P}<0.05$ vs. propofol. HMGA2, High Mobility Group AT-Hook 2.

HMGA2 mediates the effect of propofol on Wnt/ $\beta$-catenin signaling activation, we examined the expression of Wnt3a, $\beta$-catenin, Snaill and c-myc in HepG2 cells following transfection with the HMGA2-pcDNA3.1 plasmid and treatment with $20 \mu \mathrm{g} / \mathrm{ml}$ propofol for $24 \mathrm{~h}$. The results from western blot analysis showed that propofol treatment induced significant downregulation of Wnt3a, $\beta$-catenin, Snaill and c-myc in HepG2 cells $(\mathrm{P}<0.01)$. However, overexpression of HMGA2 was able to attenuate the inhibitory effect of propofol on $\mathrm{Wnt} / \beta$-catenin signaling activation. The relative protein levels of Wnt3a, $\beta$-catenin, Snaill and c-myc in the propofol + HMGA2 group were significantly higher than that in the propofol group $(\mathrm{P}<0.01$; Fig. 7$)$.

\section{Discussion}

Propofol is a commonly used intravenous anesthetic in tumor surgery. Increasing evidence has shown that propofol can effectively modulate the behavior of numerous human cancer cell types in vitro and in vivo (8-10). For example, propofol can effectively inhibit cell proliferation and invasion of cervical cancer, pancreatic cancer (11), gastric cancer (12) and colon carcinoma (10). Propofol treatment also resulted in the apoptosis of pancreatic cancer cells (11), gastric cancer cells (12), and promyelocytic leukemia cells (22). Animal studies have shown that propofol can modulate the immune reaction to exert its antitumor activity (23). Consistent with the previous studies $(13,14)$, in the present study, it was demonstrated that propofol could inhibit cell proliferation and invasion, and

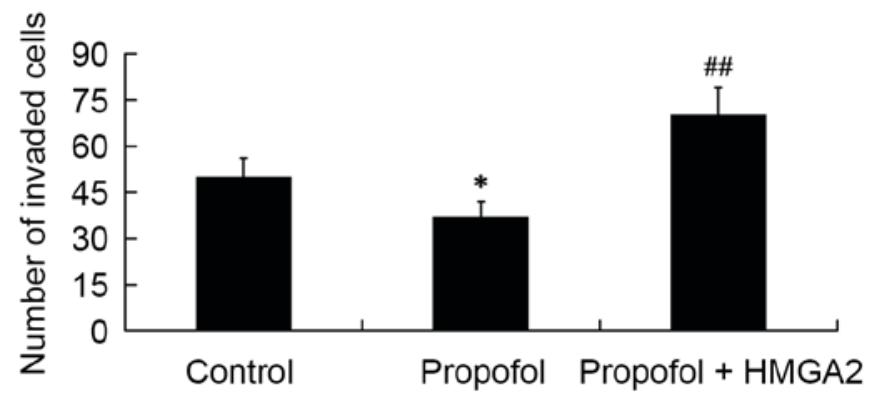

Figure 6. Role of HMGA2 in mediating the effect of propofol on cell invasion. " $\mathrm{P}<0.05$ vs. control; ${ }^{\# \prime} \mathrm{P}<0.01$ vs. propofol. HMGA2, High Mobility Group AT-Hook 2.

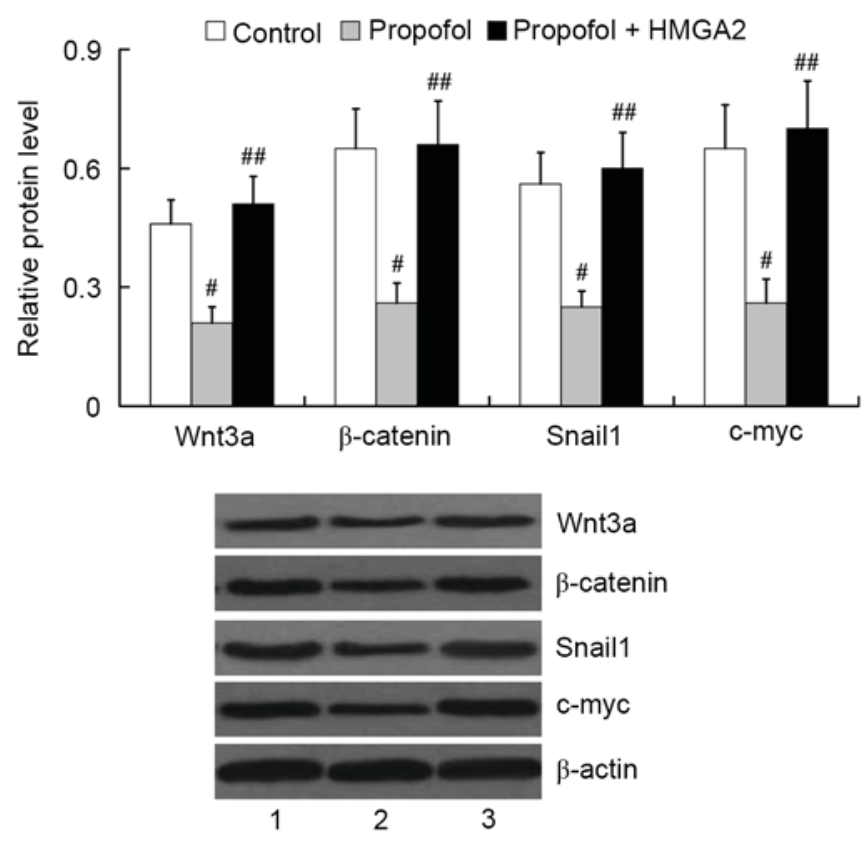

Figure 7. Role of HMGA2 in mediating the effect of propofol on Wnt/ $\beta$-catenin signaling activation. Lane 1 , control; lane 2, propofol; lane 3,

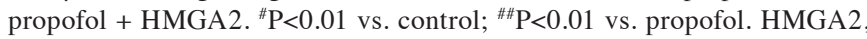
High Mobility Group AT-Hook 2; Snail1, Snail Family Zinc Finger 1.

induce cell apoptosis of HCC cells, indicating that propofol has an anti-HCC effect.

Previous studies have suggested that microRNAs (miRNAs) are involved in mediating the effects of propofol on anti-cancers, including miR-199a, miR-142-3p, miR-143 and let-7 $(13-15,24,25)$. Propofol can influence the expression of these miRNAs, which in turn are able to regulate their target mRNAs to affect the behavior of cancer cells. Using miRanda prediction software, it was indicated that HMGA2 is a potential target of miR-142-3p and let-7. Based on this, the present study investigated whether propofol could influence the expression of HMGA2. The results from western blot analysis demonstrated that HMGA2 protein expression was significantly inhibited by propofol at concentrations between 5 and $20 \mu \mathrm{g} / \mathrm{ml}$, and the inhibitory effect of propofol on HMGA2 expression was dose-dependent.

HMGA2 is an architectural transcriptional regulator that binds AT-rich DNA sequences. In a prior study, HMGA2 could not be detected in normal adult tissues (26); however, 
elevated expression of HMGA2 is found in a variety of human cancers, such as lung cancer, colorectal cancer and breast cancer (27-29). The role of HMGA2 in normal and HCC cell growth is well established $(17,18)$. HMGA2 is a marker for hepatic progenitor cells. It is expressed in all hepatoblastomas and a subset of HCCs (17). Expression of HMGA2 is associated with poor survival in patients with HCC (30). The present gain-of-function experiments found that the effect of propofol on HepG2 cell proliferation, apoptosis and invasion could be attenuated by HMGA2 overexpression. These results suggested that HMGA2 mediates the effect of propofol on HCC.

Wnt/ $\beta$-catenin pathway is the downstream pathway of HMGA2 (21). Aberrant Wnt/ $\beta$-catenin signaling has been implicated in the pathogenesis of multiple tumors $(31,32)$. Snail1 and c-myc are the downstream effectors of the Wnt/ $\beta$-catenin signaling $(33,34)$. Snail1 is involved in the induction of EMT, contributing to the invasion and migration of cancer cells (35), and c-myc is a transcription factor that regulates cell cycle, apoptosis and growth (36). Lee et al demonstrated that the expression of HMGA 2 and $\beta$-catenin correlated positively in hepatoblastoma (17). In the present study, the effect of propofol on Wnt/ $\beta$-catenin pathway was investigated. We demonstrated for the first time that propofol inhibits the $\mathrm{Wnt} / \beta$-catenin pathway in a dose-dependent manner, as evidenced by the decreased expression of Wnt3a, $\beta$-catenin, Snaill and c-myc in HepG2 cells following treatment with propofol at concentrations between 5 and $20 \mu \mathrm{g} / \mathrm{ml}$. Furthermore, we found that the effect of propofol on the Wnt/ $\beta$-catenin pathway was attenuated by HMGA2 overexpression. These results indicated that HMGA2 was involved in mediating the effect of propofol on Wnt/ $\beta$-catenin pathway in HepG2 cells.

Collectively, the present results provide the first evidence, to our knowledge, that HMGA2 mediates the effect of propofol on HepG2 cells. Propofol was able to downregulate the expression of HMGA2, which inhibited the Wnt/ $\beta$-catenin pathway, thus leading to the inhibition of cell proliferation and invasion, as well as induction of cell apoptosis of HepG2 cells. These findings suggest a novel molecular mechanism underlying the therapeutic effect of propofol on HCC. Further studies in vivo are required to validate this molecular mechanism and its clinical relevance.

\section{References}

1. Gomes MA, Priolli DG, Tralhão JG and Botelho MF: Hepatocellular carcinoma: Epidemiology, biology, diagnosis, and therapies. Rev Assoc Med Bras (1992) 59: 514-524, 2013

2. Herszényi L and Tulassay Z: Epidemiology of gastrointestinal and liver tumors. Eur Rev Med Pharmacol Sci 14: 249-258, 2010.

3. Ribatti D, Vacca A, Nico B, Sansonno D and Dammacco F: Angiogenesis and anti-angiogenesis in hepatocellular carcinoma. Cancer Treat Rev 32: 437-444, 2006.

4. Pang RW and Poon RT: From molecular biology to targeted therapies for hepatocellular carcinoma: The future is now. Oncology 72 (Suppl 1): S30-S44, 2007.

5. Castroagudín JF, Delgado M, Villanueva A, Bustamante M, Martínez J, Otero E, Tomé S, Martínez SM, Segade FR, Conde R, et al: Safety of percutaneous ethanol injection as neoadjuvant therapy for hepatocellular carcinoma in waiting list liver transplant candidates. Transplant Proc 37: 3871-3873, 2005.
6. Gluer AM, Cocco N, Laurence JM, Johnston ES, Hollands MJ, Pleass HC, Richardson AJ and Lam VW: Systematic review of actual 10-year survival following resection for hepatocellular carcinoma. HPB (Oxford) 14: 285-290, 2012

7. Zhou XD: Recurrence and metastasis of hepatocellular carcinoma: Progress and prospects. Hepatobiliary Pancreat Dis Int 1: 35-41, 2002.

8. Altenburg JD, Harvey KA, McCray S, Xu Z and Siddiqui RA A novel 2,6-diisopropylphenyl-docosahexaenoamide conjugate induces apoptosis in T cell acute lymphoblastic leukemia cell lines. Biochem Biophys Res Commun 411: 427-432, 2011.

9. Mammoto T, Mukai M, Mammoto A, Yamanaka Y, Hayashi Y, Mashimo T, Kishi Y and Nakamura H: Intravenous anesthetic, propofol inhibits invasion of cancer cells. Cancer Lett 184: 165-170, 2002.

10. Miao Y, Zhang Y, Wan H, Chen L and Wang F: GABA-receptor agonist, propofol inhibits invasion of colon carcinoma cells. Biomed Pharmacother 64: 583-588, 2010.

11. Wang ZT, Gong HY, Zheng F, Liu DJ and Dong TL: Propofol suppresses proliferation and invasion of pancreatic cancer cells by upregulating microRNA-133a expression. Genet Mol Res 14: 7529-7537, 2015.

12. Wang ZT, Gong HY, Zheng F, Liu DJ and Yue XQ: Propofol suppresses proliferation and invasion of gastric cancer cells via downregulation of microRNA-221 expression. Genet Mol Res 14: 8117-8124, 2015.

13. Zhang J, Zhang D, Wu GQ, Feng ZY and Zhu SM: Propofol inhibits the adhesion of hepatocellular carcinoma cells by upregulating microRNA-199a and downregulating MMP-9 expression. Hepatobiliary Pancreat Dis Int 12: 305-309, 2013.

14. Zhang J, Wu GQ, Zhang Y, Feng ZY and Zhu SM: Propofol induces apoptosis of hepatocellular carcinoma cells by upregulation of microRNA-199a expression. Cell Biol Int 37: 227-232, 2013.

15. Zhang J, Shan WF, Jin TT, Wu GQ, Xiong XX, Jin HY and Zhu SM: Propofol exerts anti-hepatocellular carcinoma by microvesicle-mediated transfer of miR-142-3p from macrophage to cancer cells. J Transl Med 12: 279, 2014.

16. Morishita A,Zaidi MR, Mitoro A, Sankarasharma D, Szabolcs M, Okada Y, D'Armiento J and Chada K: HMGA2 is a driver of tumor metastasis. Cancer Res 73: 4289-4299, 2013.

17. Lee CT, Zhang L, Mounajjed T and Wu TT: High mobility group AT-hook 2 is overexpressed in hepatoblastoma. Hum Pathol 44: 802-810, 2013

18. Marijon H,Dokmak S, Paradis V,Zappa M, Bieche I, Bouattour M, Raymond E and Faivre S: Epithelial-to-mesenchymal transition and acquired resistance to sunitinib in a patient with hepatocellular carcinoma. J Hepatol 54: 1073-1078, 2011.

19. Tan EJ, Thuault S, Caja L, Carletti T, Heldin $\mathrm{CH}$ and Moustakas A: Regulation of transcription factor Twist expression by the DNA architectural protein high mobility group A2 during epithelial-to-mesenchymal transition. J Biol Chem 287: 7134-7145, 2012

20. Thuault S, Tan EJ, Peinado H, Cano A, Heldin $\mathrm{CH}$ and Moustakas A: HMGA2 and Smads co-regulate SNAIL1 expression during induction of epithelial-to-mesenchymal transition. J Biol Chem 283: 33437-33446, 2008.

21. Zha L, Zhang J, Tang W, Zhang N, He M, Guo Y and Wang Z: HMGA2 elicits EMT by activating the Wnt/ $\beta$-catenin pathway in gastric cancer. Dig Dis Sci 58: 724-733, 2013.

22. Tsuchiya M, Asada A, Arita K, Utsumi T, Yoshida T, Sato EF, Utsumi $\mathrm{K}$ and Inoue $\mathrm{M}$ : Induction and mechanism of apoptotic cell death by propofol in HL-60 cells. Acta Anaesthesiol Scand 46: 1068-1074, 2002.

23. Inada T, Kubo K and Shingu K: Possible link between cyclooxygenase-inhibiting and antitumor properties of propofol. J Anesth 25: 569-575, 2011.

24. Su Z, Hou XK and Wen QP: Propofol induces apoptosis of epithelial ovarian cancer cells by upregulation of microRNA let-7i expression. Eur J Gynaecol Oncol 35: 688-691, 2014.

25. Ye Z, Jingzhong L, Yangbo L, Lei C and Jiandong Y: Propofol inhibits proliferation and invasion of osteosarcoma cells by regulation of microRNA-143 expression. Oncol Res 21: 201-207, 2013.

26. Zhou X, Benson KF, Ashar HR and Chada K: Mutation responsible for the mouse pygmy phenotype in the developmentally regulated factor HMGI-C. Nature 376: 771-774, 1995.

27. Langelotz C, Schmid P, Jakob C, Heider U, Wernecke KD, Possinger $\mathrm{K}$ and Sezer O: Expression of high-mobility-group-protein HMGI-C mRNA in the peripheral blood is an independent poor prognostic indicator for survival in metastatic breast cancer. Br J Cancer 88: 1406-1410, 2003. 
28. Wang X, Liu X, Li AY, Chen L, Lai L, Lin HH, Hu S, Yao L, Peng J, Loera $\mathrm{S}$, et al: Overexpression of HMGA2 promotes metastasis and impacts survival of colorectal cancers. Clin Cancer Res 17: 2570-2580, 2011.

29. Sarhadi VK, Wikman H, Salmenkivi K, Kuosma E, Sioris T, Salo J, Karjalainen A, Knuutila S and Anttila S: Increased expression of high mobility group A proteins in lung cancer. J Pathol 209: 206-212, 2006.

30. Wu L, Wang Z, Lu R and Jiang W: Expression of high mobility group A2 is associated with poor survival in hepatocellular carcinoma. Pathol Oncol Res 18: 983-987, 2012.

31. Gupta A, Verma A, Mishra AK, Wadhwa G, Sharma SK and Jain CK: The Wnt pathway: Emerging anticancer strategies. Recent Pat Endocr Metab Immune Drug Discov 7: 138-147, 2013.
32. Rosenbluh J, Wang $X$ and Hahn WC: Genomic insights into WNT/ $\beta$-catenin signaling. Trends Pharmacol Sci 35: 103-109, 2014.

33. Dai C, Stolz DB, Kiss LP, Monga SP, Holzman LB and Liu Y: Wnt/beta-catenin signaling promotes podocyte dysfunction and albuminuria. J Am Soc Nephrol 20: 1997-2008, 2009.

34. Breuhahn K, Longerich T and Schirmacher P: Dysregulation of growth factor signaling in human hepatocellular carcinoma. Oncogene 25: 3787-3800, 2006.

35. Baulida J and García de Herreros A: Snail1-driven plasticity of epithelial and mesenchymal cells sustains cancer malignancy. Biochim Biophys Acta 1856: 55-61, 2015.

36. Vita $\mathrm{M}$ and Henriksson $\mathrm{M}$ : The Myc oncoprotein as a therapeutic target for human cancer. Semin Cancer Biol 16: 318-330, 2006. 